calomel electrode at $30^{\circ} \mathrm{C}$. (This temperature was used because of the high ambient temperature.) To measure the wave-height draw a straight line through the curve at $-0.6 \mathrm{~V}$. and $-1.0 \mathrm{~V}$. and extend to meet the $-1.3 \mathrm{~V}$. perpendicular. The vertical distance between this intersection and the wave at $-1 \cdot 7 \mathrm{~V}$. gives the wave-height.

The gamma isomer concentration is read from a standard curve prepared using pure gamma isomer. A convenient range for this curve is $3-15 \mathrm{mgm}$. gamma isomer, this yielding a straight line, not passing through the origin.

Further aliquots of the alcohol extract are analysed for total benzene hexachloride by normal dehydrohalogenation methods, and the ratio gamma isomer/ total benzene hexachloride calculated.

The method of extracting the benzene hexachloride is essentially that of Hitcheock et al., as briefly described by Mackerras4, while the empirical method of wave measurement is similar to that of Dragt $^{2}$.

I wish to thank the Chief Veterinary Research Officer, 'Tanganyika, for the constant interest he has shown during the development of this method, and the Director of Veterinary Services, Tanganyiks, for permission to publish this account.

Veterinary Research Laboratories,

$$
\text { G. W. WALKer }
$$

Mpwapwa, Tanganyika.

$$
\text { March } 2 .
$$

${ }^{1}$ Downing, W., Harbour, H. E., and Stores, L. A., British Veterinary Association Congress, i952.

2 Dragt, G., Anal. Chem., 20, 737 (1948).

${ }^{3}$ Ingam, G. B., and Southern, H. K., Nature, 161, 437 (1948).

- Mackerras, I. M., Austral. Vet. J., 23, 185 (1947).

\section{Isolation from the Lower Respiratory Tract of Chickens of Bacteria administered by Mouth}

IT is generally assumed that bacteria ingested in food or water do not enter the trachea but that all of them pass down the osophagus. One interesting observation in this respect was made by White and Minett ${ }^{1}$, who noted that when calves were fed milk containing Mycobacterium tuberculosis primary lesions of tuberculosis were sometimes found in the lungs, indicating that some of the bacteria administered may have been aspirated into the lungs. More direct evidence that this may occur was obtained as a result of some experiments that were designed to trace the route by which Salmonella gallinarum enters the body following its administration to chickens by mouth.

In the initial studies large numbers of Salm. gallinarum bacteria were mixed in a commercial mash and fed to chickens which were then killed at different times and selected organs cultured. Salm. gallinarum was isolated from the lungs of an unexpectedly high proportion of chickens, in some after an interval of time so short as to preclude them having reached this organ via the intestine.

In view of this, four groups each consisting of fifteen nine-week-old chickens were taken. The first group was fasted for $12 \mathrm{hr}$. and then fed on a commercial mash into which had been mixed an 18-hr. broth culture of Salm. gallinarum, $1 \mathrm{ml}$. per $10 \mathrm{gm}$. of mash. The culture contained approximately $50 \times 10^{7}$ bacteria per ml. Water was withheld from the second group for $12 \mathrm{hr}$. This group was then provided with drinking water, every $10 \mathrm{ml}$. of which contained $1 \mathrm{ml}$. of the broth culture. $1 \mathrm{ml}$. of the culture was placed carefully into the mouth of the chickens in the third group by means of a pipette. A similar amount of culture was given to the fourth group by means of a pipette introduced via the mouth into the cesophagus, care being taken to avoid touching the epiglottis.

The chickens were killed $\frac{3}{4} \mathrm{hr}$. later by dislocation of the neck, and, at the same time, a pair of strong artery forceps was fixed, through the skin, around the upper portion of the trachea so as to occlude its orifice. A post-mortem examination was then carried out using aseptic precautions. Cultures were made from the mucous membrane of the lower end of the trachea on to deoxycholate-citrate agar ${ }^{2}$ and a portion about 1 in. long of this part of the trachea placed in a tube of selenite- $\mathrm{F}$ medium ${ }^{3}$. Most of the left lung was removed, ground in sterile sand and one loopful of this streaked on to a plate of deoxycholate-citrate agar; the remainder was placed in a tube of selenite-F medium. The selenite-F cultures were incubated at $37^{\circ} \mathrm{C}$. for $24 \mathrm{hr}$. and plated on to deoxycholate-citrate agar. All plates of the latter medium were incubated at $37^{\circ} \mathrm{C}$. for $24 \mathrm{hr}$. and then examined for the presence of Salm. gallinarum. The results are shown in Table 1.

\begin{tabular}{|c|c|c|c|}
\hline $\begin{array}{l}\text { Method of administering } \\
\text { Salm. gallinarum }\end{array}$ & $\begin{array}{l}\text { No. of } 1 \\
\text { galline } \\
\text { Trachea }\end{array}$ & $\begin{array}{l}\text { hicken } \\
\text { im. was } \\
\text { Lung }\end{array}$ & $\begin{array}{l}\text { which Salm. } \\
\text { olated from } \\
\text { Trachea. } \\
\text { and/or lung }\end{array}$ \\
\hline $\begin{array}{l}\text { In food } \\
\text { In drinking water } \\
\text { Into mouth by pipette } \\
\text { Into osophagus by pipette }\end{array}$ & $\begin{array}{l}4 \\
4 \\
9 \\
0\end{array}$ & $\begin{array}{r}10 \\
5 \\
3 \\
0\end{array}$ & $\begin{array}{r}12 \\
7 \\
10 \\
0\end{array}$ \\
\hline
\end{tabular}

\section{Table 1}

Salm. gallinarum was not isolated from the lower respiratory tract of any of the fifteen chickens to which it was given by means of a pipette into the œesophagus. Quite different results were obtained when it was administered by the other three methods, Salm. gallinarum being recovered from the trachea or lungs of a considerable proportion of these chickens. It is noteworthy that Salm. gallinarum was isolated more frequently from the trachea than from the lungs of the chickens to which it was given by pipette into the mouth $(9-3)$; the reverse was true in the case of the chickens fed infected food $(4-10)$.

Salm. gallinarum was only isolated by direct culture in one case, from the trachea of a chicken given this organism by pipette into the mouth. The other isolations were made through selenite-F medium. It is therefore probable that infection via the lower respiratory tract would be of little significance under natural conditions since chickens would not be exposed to such large numbers of bacteria. However, it is a point to be borne in mind when the production of experimental infections is under consideration.

\section{H. Williams Smith}

Animal Health Trust,

Houghton Grange,

Huntingdon.

$$
\text { Feb. } 26 .
$$

1 White, E. G., and Minett, F. C., Brit. J. Tubercul., 35, 69 (1941). Hynes, M., J. Path. Bact., 54, 193 (1942).

3 Hobbs. B. C., and Allison, V. D., Mon. Bull. Min. Bealth, Lond., 